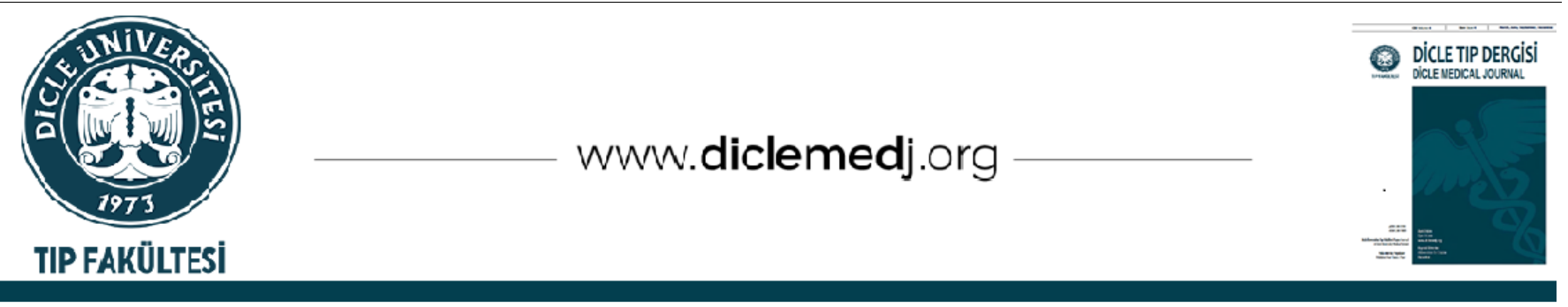

\title{
Kronik Otitis Media'da Tiyol-Disülfid Homeostazının Değişikliği
}

\author{
Muhammed Ayral ${ }^{i D_{1}}$, Serdar Ferit Toprak ${ }^{i}{ }_{1}$, Serkan Dedeoğlu ${ }^{i}{ }_{2}$, Illhan Sabancılar ${ }^{i}{ }_{3}$, Hakan Temiz ${ }^{D_{4}}$ \\ 1 Dicle Üniversitesi Tıp Fakültesi, Kulak Burun ve Boğaz Hastalıkları Kliniği. Diyarbakır, Türkiye \\ 2 Sağlık Bilimleri Üniversitesi, Gazi Yaşargil Eğitim ve Araștırma Hastanesi, Kulak Burun ve Boğaz Hastalıkları Kliniği. Diyarbakır, Türkiye \\ 3 Dicle Üniversitesi Veteriner Fakültesi, Biyokimya AD. Diyarbakır, Türkiye \\ 4 Dicle Üniversitesi Tıp Fakültesi, Mikrobiyoloji AD. Diyarbakır, Türkiye
}

Geliș: 27.08.2020; Revizyon: 08.02.2021; Kabul Tarihi: 15.02.2021

$\ddot{0} \mathbf{z}$

Giriş: Bu çalışmada kronik otitis medialı hastalarda oksidan ve antioksidan dengenin yeni bir oksidatif stres indikatörü olan dinamik TiyolDisülfid Homeostazı'nın, serumda native tiyol, total tiyol ve disülfit seviyelerinin tespiti ve disulfid/total tiyol ve disulfid/native tiyol oranlarının saptanmasını amaçladık.

Yöntemler: Tüm hastalar saf ton odyometrisi ve temporal kemiğin bilgisayarlı tomografisi ile incelendi. Mastoid hücrelerde granülasyon dokusu ve BT'de orta kulakta yumuşak doku yoğunluğu gösteren hastalar çalışma için seçildi. Kontrol grubu, herhangi bir tıbbi öyküsü olmayan ve normal fizik muayenesi olan asemptomatik olan 59 sağlıklı kişiden oluşuyordu. Çalışmaya tanısı otomikroskobik muayene ve odyolojik testlerle ile doğrulanmış 18-60 yaş arası toplamda 59 kronik otitis medialı hasta ve kontrol grubunda ise benzer yaş aralığında 59 sağlıklı gönüllü çalışmaya alınmıştır. Tiyol-Disülfid Homeostazı parametreleri; ticari kitler (Rel Assay Diagnostics, Türkiye) kullanılarak spektrofotometrik olarak ölçülmüștür.

Bulgular: Çalışmaya dahil edilen toplam 118 katılımcının yarısını vaka diğer yarısı da kontrol grubu oluşturmaktadır. Çalışmaya dahil edilen

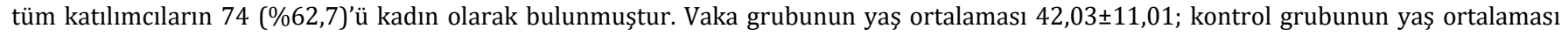
$41,47 \pm 10,90$ olarak bulunmuştur. Vaka ve kontrol grubundaki katılımcıların çeşitli kan değerleri ve oranları karşılaştırılmıștır. Vaka grubundakilerin; kan native tiyol $(399,27 \pm 41,57)$ ve total tiyol $(411,30 \pm 42,15)$ düzeyleri kontrol grubundaki native tiyol $(422,13 \pm 41,03)$ ve total tiyol $(435,93 \pm 44,03)$ değerlerden anlamlı derecede düşük bulunmuştur $(\mathrm{p}<0.01)$. Vaka grubunun disülfid değerleri $(21,18 \pm 4,57)$ kontrol grubundaki disülfid $(19,87 \pm 5,01)$ değerinden fazla bulunmakla beraber aralarında istatistiksel olarak anlamlı bir fark saptanamamıştır $(\mathrm{p}>0.05)$.

Sonuç: Sonuç olarak, mevcut sonuçlar kronik otitis medialı hastalarda dinamik tiyol değişikliklerinin önemli ölçüde bozulduğunu göstermiştir. Kronik otitis medianın tedavisinde antioksidan tedavisi eklemenin ne kadar etkili olabileceği, tedavi modalitelerini değiştirip değiştirmeyeceğini, cerrahinin mutlak üstünlüğünü kırıp kıramayacağını öğrenmek için daha geniş klinik çalışma ve gözleme ihtiyaç bulunmaktadır.

Anahtar kelimeler: Toplam tiyol seviyesi, disülfid seviyesi, Tiyoldisülfid Homeostaz, Kronik otitis media

DOI: 10.5798/dicletip.887718

Correspondence / Yazıșma Adresi: Hakan Temiz, Dicle Üniversitesi Tıp Fakültesi, Mikrobiyoloji AD. Diyarbakır, Türkiye e-mail: hakan.temiz@dicle.edu.tr 


\title{
Alteration Of Thiol-Disulphide Homeostasis In Chronic Otitis Media
}

\begin{abstract}
Objectives: We aimed to invastigate dynamic thiol-disulfide homeostasis, a new oxidative stress marker of oxidant and antioxidant balance, serum native thiol, total thiol and disulfide levels in patients with chronic otitis media in this study.

Method: A total of 59 patients with chronic otitis media between the ages of 18-60 and 59 healthy volunteers in the same age group were included in this study whose diagnosis was confirmed by otomicroscopic examination and audiological tests.The control group consisted of 59 healthy individuals who were asymptomatic with no medical history and normal physical examination. Pure tone audiometry and computed tomography of temporal bone were examined in all patients. Patients showing granulation tissue in mastoid cells and soft tissue density in the middle ear on computed tomography were selected for the study. Thiol-disulfide homeostasis parameters were measured by the spectrophotometric method using commercially avaible kits (Rel Assay Diagnostics, Turkey).
\end{abstract}

Results: Half of the 118 participants included in this study were cases and the other half constituted the control group. 74 (62,7\%) of all participants included in the study were found to be women. The mean age of the case group was 42,03 $\pm 11,01$; the average age of the control group was $41,47 \pm 10,90$. Various blood values and rates of the participants in the case and control groups were compared. Blood levels of native thiol $(399,27 \pm 41,57)$ and total thiol $(411,30 \pm 42,15)$ in the case group were determined as native thiol $(422,13$ $\pm 41,03)$ and total thiol $(435,93 \pm 44,03)$ was significantly lower than the values of the control groups ( $<<0.01)$. Disulphide values of the case group $(21,18 \pm 4,57)$ were higher than the disulphide value in the control group $(19,87 \pm 5,01)$; but no significant difference was found between them, statistically ( $\mathrm{p}>0.05)$.

Conclusion: In conclusion, the present results obtained from this study indicated that dynamic thiol changes were significantly impaired in patients with chronic otitis media. Further clinical studies and observations are needed to find out how effective the addition of antioxidant therapy can be in the treatment of chronic otitis media, whether it will change the treatment modalities, or whether it can break the absolute dominance of surgery.

Keywords: Total thiol level, disülfide level, Thiol Disülfide Homeostasis, Chronic otitis media.

\section{GíRiş}

Kronik otitis media (KOM), timpanik membran perforasyonu, otore, duyma kayıpları ile karakterize, 3 aydan daha uzun süren ve medikal tedaviye rağmen tamamen düzelmeyen orta kulaktaki kronik bir inflamasyondur ${ }^{1}$. Birçok çalışma kronik otitis medianin predispozan faktörlerini ve patogenezini araştırmıştır. Genetik, östaki tüp disfonksiyonu, otoimmünite, enfeksiyon, osteoklastik aktivite, sitokinler, endotoksinler ve oksidatif strese bağlı lipit peroksidasyon ürünleri gibi birçok neden otitis media'daki enflamasyonun kronikliğinden sorumlu tutulmuştur ${ }^{2,3}$. Bu kronik sürecin neden olduğu doku hasarından birçok faktör sorumlu tutulsada, olayın patofizyolojisi hala net değildir. Oksidan ve onu dengeleyen antioksidan mekanizmalar arasındaki balansın bozulması oksidatif stres olarak kabul edilir. Geçmiş yıllarda yapılan çalışmalarda; multifaktöriyel inflamatuvar bir hastalı olan kronik otitis medianın etyolojisinde oksidatif stresin rolünün olabileceği bildirilmiştir ${ }^{4}$. Aeorobik canlılarda normal metabolik süreçte sürekli olarak reaktif türler meydana gelir. Elektron transport zinciri, sitokrom P450 enzimleri, nikotinamid adenin dinükleotid oksidaz kompleksi, ksantin oksidaz ve peroksizomların katıldığı pek çok enzim aracılı reaksiyonda oksidatif ürünler oluşur. Ultraviyole işınlara maruziyet, çeşitli kimyasal bileşikler, çevre kirliliği ve sigara gibi pek çok dış etken de oksidatif ürünlerin oluşmasına neden olur. Bu ürünler sinyal iletimi, enzim aktivasyonu, bağışıklık sisteminin düzenlenmesi, gen ekspresyonu, yeni sentezlenen proteinlerin katlanması esnasında disülfid bağlarının oluşumu, apoptozis gibi çeşitli fizyolojik süreçlerde görevde alırlar5. Oksidatif strese bağlı olarak ortaya çlkan oksidatif ürünlerin yetersiz yada defektif antioksidan savunma mekanizmasına bağlı olarak aşırı üretimi kronik oksidatif strese neden olmakta ve bu durum KOM gelişiminde önemli bir faktör olan inflamasyonu 198 
arttırmaktadır. Oksidatif stres durumunda oluşan oksidan ürünler hücrelerin ana yapısı olan özellikle proteinler, lipitler ve nükleik asitler başta olmak üzere birçok ana moleküle zarar verir6.

Tiyol grubu içeren bileşikler indirgeyici özellikleri ile oksidatif strese karşı savunmada önemli görevi olan organik maddelerdir. Plazmada bulunan başlıca tiyoller; albümin tiyolleri, protein tiyolleri ve sistein, sisteinilglisin, glutatyon, homosistein ve $\gamma$ glutamilsisteinin yer aldığı düşük molekül ağırlıklı tiyollerdir. Organizmada oluşan reaktif oksijen türleri gibi oksidatif ürünler fazla elektronlarını tiyol içeren bileşiklere aktararak indirgenirken tiyol grupları okside olur. Tiyol gruplarının okside olması disülfid bağlarının oluşmasina neden olur. Ancak bu geri dönüşümlü bir reaksiyondur ve oluşan disülfid bağları tekrar tiyol gruplarına indirgenebilir. Böylece dinamik tiyol-disülfit homeostazı (TDH) sağlanmış olur?.

Dinamik tiyol-disülfit homeostazının ölçülmesi ile normal veya anormal pek çok biyokimyasal sürece ilişkin bilgiler elde edilebilir. $\mathrm{Bu}$ homeostazın immünetyopatogenezinde çok önemli rolünün olduğu ve tiyol-disülfit homeostazındaki bozulmanın oksidatif stres ve doku inflamasyonu sayesinde hastalığı harekete geçirdiği düşünülmektedir.

$\mathrm{Bu}$ çalışmada; kronik otitis medialı hastalarda yeni bir oksidatif stres indikatörü olan dinamik TDH'nın, serum native tiyol(sh), total tiyol(tt) ve disülfid(ss) seviyelerinin tespiti ve disulfid/total tiyol ve disulfid/native tiyol oranlarının saptanmasını amaçladık.

\section{YÖNTEMLER}

$\mathrm{Bu}$ çalışmada; çalışmaya katılmış kişilerden bilgilendirilmiş onam alındıktan sonra sağlıklı gönüllüleri içeren 18-60 yaş arası, kronik otitis medialı hastalar ve sağlıklı olan kontrol grubu arasındaki dinamik TDH'nin karșılaștırması amaçlandı. Bu çalışma, Nisan 2018 ile Nisan 2019 arasında Diyarbakır Gazi Yaşargil Eğitim ve Araştırma Hastanesi Kulak Burun Boğaz Anabilim Dalı'nda gerçekleştirildi. Hastalara anamnez ve otomikroskopik inceleme ile KOM tanısı kondu. Tüm hastalar saf ton odyometrisi ve temporal kemiğin bilgisayarlı tomografisi (BT) ile incelendi. Mastoid hücrelerde granülasyon dokusu ve BT'de orta kulakta yumuşak doku yoğunluğu gösteren hastalar çalışma için seçildi. Kontrol grubu, herhangi bir tıbbi öyküsü olmayan ve normal fizik muayenesi olan asemptomatik olan 59 sağlıklı kişiden oluşuyordu. Kontrol deneklerinin hiçbiri, E ve C vitaminleri gibi antioksidan vitamin takviyesi almıyordu. Ayrıca, deneklerin herhangi bir ilaç, sigara ve alkol kullanımı yoktu. Çalışmaya tanısı otomikroskobik muayene ve odyolojik testlerle ile doğrulanmış 18-60 yaş arası toplamda 59 kronik otitis medialı hasta dahil edilmiştir. Çalışmaya dahil edilen hastalardan bilgilendirilmiş onam alınmıștır. Ayrıca; Sağlık Bilimleri Üniversitesi, Gazi Yaşargil Eğitim ve Araştırma Hastanesi Klinik Araştırmalar Etik Kurulu'ndan 438 sayılı etik kurul onayı alınmıștır.

Hastaların yaş, cinsiyet, sistolik ve diastolik kan basınçları ve beden kitle indeksleri kaydedilmiştir.

\section{Dışlama Kriterleri}

Diabetes mellitus, obezite, hipertansiyon, kalp yetmezliği gibi herhangi bir kardiovasküler ve serebrovasküler hastalık, akut ya da kronik böbrek ya da karaciğer hastalığl, enfeksiyon, romatizmal hastalık, malignite gibi bir inflamatuvar hastalık tanısı almış olan hastalar, lipid düşürücü ajan, vitamin ya da herhangi bir anti-oksidan madde dahil ilaç kullanımı olan, alkol ve sigara öyküsü olan hastalar çalışma dışı kabul edilmiştir. 


\section{Kan örnekleri}

Kronik otitis medialı hastalar ve bu çalışmaya katılmış kişilerden veya bu kişilerin

vasilerinden bilgilendirilmiş onam alındıktan sonra sağlıklı gönüllüleri içeren bu çalışmada Erel ve ark.7 tarafından geliștirilen yeni, tamamen otomatik bir metod ile dinamik TDH'ını gösteren plazma native tiyol, total tiyol ve disülfid seviyeleri ticari kitler (Rel Assay Diagnostics, Türkiye) kullanılarak spektrofotometrik olarak ölçülmüştür. Tiyol/disülfid kan seviyelerini ölçmek amacıyla 8 saatlik açlık ardından kan örnekleri biyokimya tüpüne alındı. Alınan kan örnekleri 10 dakika süre ile 1500 rpm hızda santrifüj edildikten sonra $-80^{\circ} \mathrm{C}$ 'de çalışma gününe kadar saklandı. $\mathrm{Bu}$ testin çalışma esası olarak; redüklenebilen disülfid bağları serbest fonksiyonel tiyol gruplarını oluşturacak şekilde indirgendi. Artık sodyum borohidrit ve DTNB (5,5'-dithiobis-2nitrobenzoic acid)) ürünlerini uzaklaştırmak amacıyla formaldehit kullanıldı. Daha sonra hem indirgenmiş hem de native doğal tiyol grupları saptandı. Dinamik disülfid bağlarının miktarı total tiyol ve native tiyol grupları arasındaki farkın yarısı saptanarak bulundu. Native, total tiyol, disülfid miktarlarının hesaplanması sonrası disulfid/total tiyol yüzde oranları, native tiyol/total tiyol oranları ve disulfid/native tiyol yüzde oranları saptandı. Disülfid seviyeleri ve bu oranlar kronik otitis medialı hastalarda ve kontrol grubunda karşılaştırıldı.

\section{İstatistiksel Analiz}

Çalışmadaki veriler; n (\%) değerleri, sürekli veriler de ise ortalama \pm standart sapma (ort \pm SS) değerleri ile gösterilmiştir. Kategorik verilerin karşılaştırılmasında Kikare testi kullanılmıştır. Ölçümsel veriler normal dağılım varsayımı için Kolmogrov-Smirnov testleri ile sınanmıştır. Normal dağılım gösteren ölçümsel verilerin karşılaştırılması için bağımsız gruplarda student $\mathrm{t}$ testi kullanılmıştır. Tüm analizlerde; istatistiksel anlamlılık için $\mathrm{p}<0.05$ kabul edilmiştir. Analizler; IBMC SPSS programı 20 sürümü ile gerçekleştirilmiștir.

\section{BULGULAR}

Çalışmaya dahil edilen toplam 118 katılımcının yarısını vaka diğer yarısı da kontrol grubu oluşturmaktadır. Çalışmaya dahil edilen tüm katılımcların $74 \quad(\% 62,7)$ 'ü kadın olarak bulunmuştur. Vaka grubunun yaş ortalaması $42,03 \pm 11,01$; kontrol grubunun yaş ortalaması $41,47 \pm 10,90$ olarak bulunmuştur. Vaka ve kontrol grubunun yaș, cinsiyet dağılımı ve beden kitle indeksi arasında anlamlı bir fark bulunmamıştır ( $\mathrm{p}>0.05$ ) (Tablo 1).

Tablo II: Vaka ve Kontrol Gruplarının Cinsiyet, Yaş ve Beden Kitle İndeksi Dağılımı

\begin{tabular}{|l|l|l|l|l|}
\hline Değişkenler & & Vaka Grubu & $\begin{array}{l}\text { Kontrol } \\
\text { Grubu }\end{array}$ & $\begin{array}{l}\mathbf{p} \\
\text { değeri }\end{array}$ \\
\hline \multirow{2}{*}{ Cinsiyet } & Kadın & $35(\% 47,3)$ & $39(\% 52,7)$ & \multirow{2}{*}{$0.446^{*}$} \\
\cline { 2 - 4 } & Erkek & $24(\% 54,5)$ & $20(\% 45,5)$ & \\
\hline Yaş & & $42,03 \pm 11,01$ & $41,47 \pm 10,90$ & $0.395^{*}$ \\
\hline $\begin{array}{l}\text { Beden Kitle } \\
\text { İndeksi }\end{array}$ & & $26,42 \pm 1,56$ & $26,14 \pm 1,12$ & $0.277^{* *}$ \\
\hline
\end{tabular}

Tablo II: Vaka ve Kontrol Grubundaki Katılımclların Native tiyol, Total tiyol, Disülfid ve ss/sh, ss/tt ve sh/tt Oranlarının Karşılaştırılması

\begin{tabular}{|l|l|l|l|}
\hline Parametreler & $\begin{array}{l}\text { Vaka Grubu } \\
(\boldsymbol{\mu m o l} / \mathbf{L})\end{array}$ & $\begin{array}{l}\text { Kontrol Grubu } \\
(\boldsymbol{\mu m o l} / \mathbf{L})\end{array}$ & $\begin{array}{l}\mathbf{p} \\
\mathbf{d e g ̆ e r i}\end{array}$ \\
\hline Native Tiyol (sh) & $399,27 \pm 41,57$ & $422,13 \pm 41,03$ & $<0.01$ \\
\hline Total Tiyol (tt) & $411,30 \pm 42,15$ & $435,93 \pm 44,03$ & $<0.01$ \\
\hline Disülfid (ss) & $21,18 \pm 4,57$ & $19,87 \pm 5,01$ & $>0.05$ \\
\hline ss/sh & $5,31 \pm 1,32$ & $4,47 \pm 1,08$ & $<0.001$ \\
\hline ss/tt & $5,73 \pm 1,23$ & $4,19 \pm 1,15$ & $<0.001$ \\
\hline sh/tt & $87,21 \pm 5,79$ & $91,74 \pm 2,33$ & $<0.001$ \\
\hline
\end{tabular}


Tablo 2'de vaka ve kontrol grubundaki katılımcıların çeşitli kan değerleri ve oranları karşılaştırılmıştır. Vaka grubundakilerin kan Native tiyol $(399,27 \pm 41,57)$ ve Total tiyol $(411,30 \pm 42,15) \quad$ düzeylerinin kontrol grubundaki native tiyol $(422,13 \pm 41,03)$ ve total tiyol $(435,93 \pm 44,03)$ değerlerinden anlamlı derecede düşük bulunmuştur $(\mathrm{p}<0.01)$. Vaka grubunun disülfid değerleri $(21,18 \pm 4,57)$ kontrol grubundaki disülfid $(19,87 \pm 5,01)$ değerinden fazla bulunmuştur ancak aralarında istatistiksel olarak anlamlı bir fark bulunmamıştır ( $p>0.05)$.

Vaka grubunun ss/sh $(5,31 \pm 1,32)$ ve ss/tt $(5,73 \pm 1,23)$ oranları kontrol grubundaki ss/sh $(4,47 \pm 1,08)$ ve ss/tt $(4,19 \pm 1,15)$ değerinden anlamlı derecede fazla bulunmuştur $(\mathrm{p}<0.001)$. Vaka grubunun sh/tt $(87,21 \pm 5,79)$ oranı kontrol grubundaki sh/tt $(91,74 \pm 2,33)$ değerlerinden anlamlı derecede düşük bulunmuştur $(\mathrm{p}<0.001)$.

\section{TARTIŞMA}

Serbest oksijen radikalleri (SOR), oksijen metabolizmasındaki çeşitli biyokimyasal reaksiyonlar sonucunda endojen olarak meydana gelir. SOR, immün sistem yanıtı ve metabolik aktivite için oldukça önem arzetmektedir $^{8}$. Nötrofiller, monositler ve makrofajlar gibi vücuttaki savunma sisteminde rol alan temel hücreler, vücuda giren yabancı maddelere ve antijenlere karşı savaşırken SOR'ni meydana getirirler. SOR'nin fazla salınması, proteinleri, karbonhidratları, nükleotitleri ve lipitleri metabolize ederek kimyasal olarak değişmelerine neden olarak doku hasarına neden olduğu bilinmektedir. Böylece vücudun oluşan hasar nedeniyle doku rejenerasyonu engellenir ve enflamasyon süresi uzar. Antioksidanlar ise çeşitli biyokimyasal olaylar sonucunda endojen olarak üretilen SOR'nin hücreler üzerindeki tahrip edici etkisini önlemeye yarayan ve oksidatif bir denge sağlayan maddelerdir ${ }^{9}$. Mevcut verilere göre, oksidatif stres tümörgenezis, kardiyovasküler hastalıklar, romatoid artrit, kardiyak iskemi/reperfüzyon, kronik adenotonsillit ve yaşlanma gibi çeşitli durumların patofizyolojisinde rol oynamaktadır ${ }^{10-13}$. Araștırmalar, oksidatif stresin akut otitis media, efüzyonlu otitis media ve timpanoskleroz patofizyolojisinde de aktif rolü olduğunu göstermiştir ${ }^{14,15}$.

KOM ile oksidatif stres arasındaki bağlantıyı araştıran deneysel ve klinik çalışmalarda, SOR'nin, pro-oksidan ve antioksidan sistemler arasındaki denge bozulmasının kronik otitis media oluşumunda önemli katkısının olabileceği değerlendirilmiștir ${ }^{16}$. Son zamanlarda, çeşitli yayınlarda akut ve kronik hastalıkların fizyopatogenezinde anormal tiyol/disülfid dengesinin rol alabileceği öne sürülmektedir ${ }^{17}$. Nitekim çeşitli çalışmalarda serumdaki tiyol düzeylerinin ölçülmesinin antioksidan savunmayı dolaylı bir şekilde yansitabileceği ileri sürülmekte ve oksidatif stres altında, tiyol seviyesi azaldıkça disülfid seviyesinin artması gerektiği ortaya konulmuştur. Tiyoller, reaktif oksijen türleri aracılı hücre ve doku hasarını önlemek için serbest radikallerle reaksiyona girer. Serbest radikaller, bu oksidasyon reaksiyonunun bir sonucu olarak sülfür ve disülfür bağları içeren amino asitlerin tiyol gruplarının oksidasyonuna sebep olur. $\mathrm{Bu}$ disülfür bağları indirgeme yoluyla tiyollere dönüştürülebilir. Bu şekilde, tiyol/disülfür dengesi hücreler ve dokularda sağlanır. Böylece antioksidan savunma sistemi, detoksifikasyon, apopitoz ve enzim aktiviteleri düzenlenebilir ve hücre içi sinyal iletim mekanizmalarının düzenlenmesi sağlanır. Azalan tiyoller ve artan disülfür seviyeleri reaktif oksijen türleri ürünlerinin klerensinin azalmasına neden olur. Disülfid oluşumunun artması, birçok organ ve sistemde oksidasyon ve redoks ürünlerine karşı korumayı olumsuz 
yönde etkileyerek fonksiyonel ve yapisal patolojileri tetikler. $\mathrm{Bu}$ şekilde apopitoz ve hücresel hasar sıklığı $\operatorname{artar}^{17}$.

Birçok kronik hastalığın patogenezinde olduğu gibi, SOR yakın zamanda KOM'da enfeksiyon kronikleşmesinden ve doku hasarından sorumlu tutulmuştur. Bu çalışmalarda oksidatif stres ve antioksidan markerler olarak çeşitli parametreler kullanılmıştır. Bunlar arasında TAS (toplam antioksidan durumu), TOS (toplam oksidan durumu), PON (paraoksonaz), SOD (süperoksit dismutaz), GHPx (glutatyon peroksidaz), CAT (katalaz); malondialdehit (MDA) seviyeleri araştırılmıştır. Daha önceki çalışmalarda oksidatif stres için Yılmaz ve ark. ${ }^{15}$ seröz otitis media nedeniyle bilateral ventilasyon tüpü takılan ve adenoidektomi yapılan çocuk hastalarla sağlıklı çocuk grubunu ameliyattan 1 ay önce ve sonra olmak üzere antioksidanların (retinol, karoten, tokoferol, likopen, askorbik asit, süperoksit dismutaz, glutatyon peroksidaz ve oksidatif ürün (malondialdehit) seviyelerini karşılaştırdılar. Yapılan bu çalışmada, cerrahi girișim öncesi ve sonrası antioksidan ve oksidanların kandaki miktarları kontrol grubuna göre anlamlı olarak farklıydı $\quad(\mathrm{p}<0.05)$ Çalışma grubunda, ameliyattan sonra kan antioksidan düzeyleri artmış ve oksidan düzeyleri anlamlı düzeyde azalmıştır $\quad(\mathrm{p}<0.05)$ Oksidanlar ve antioksidanlar, çocuklarda efüzyonlu otitis media patogenezinde önemli bir rol oynamakta ve tedavi için antioksidan tedavi gerekebilmektedir. Garca ve ark. ${ }^{16}$ kronik otitisli 61 hasta ile 30 kişilik kontrol grubunda yaptıkları çalışmada; serumda miyeloperoksidaz (MPO) aktivite, 4hidroksinonenal (4-HNE), malondialdehit (MDA), total antioksidan kapasite (TAC) ve nitrikoksit (NO) değerlerini araştırdılar. Tüm değerlerde istatiksel olarak anlaml fark buldular. Serum MPO aktivite ve 4-HNE, MDA ve
NO seviyeleri, önemli derecede, hasta grubunda KOM kontrol grubundan yüksekti $(\mathrm{p}<0.001)$. Bununla birlikte; TAC seviyesi anlaml derecede düşüktü $(\mathrm{p}<0.001)$. KOM'lu hastalarda artan oksidatif seviye ve azalan antioksidatif stresin etyopatogenezde rol alabileceğini belirmişlerdir. Baysal ve ark. ${ }^{4}$ yaptıkları çalışmada serum toplam oksidan durumu (TOS) ve oksidatif stres indeksi (OSI) düzeylerini hasta ve kontrol grubunda karşılaştırdılar. Kolesteatomu olan ve olmayan KOM hastalarında toplam total antioksidan kapasite ve yüksek oksidatif stres değeri bildirmişlerdir. Serum toplam antioksidan durumu (TAS) seviyeleri ve Paraoksonaz ve arilesteraz aktivitesi, kolesteatomlu veya kolesteatom olmayan hasta gruplarında kontrol grubuna göre anlamlı olarak daha düşüktü. Biz de bu çalışmada daha önce değerlendirilmeyen bir oksidatif stres belirteci olarak yeni bir metod olarak kabul edilen tiyol-disülfid parametrelerini değerlendirdik. KOM; tanı ve tedavideki zorluklar nedeniyle Kulak Burun Boğaz Hastalıkları pratiğinde önemini hiç yitirmeyen bir konudur ${ }^{18}$. KOM hastalarında doku değerlerinin değerlendirilmesi hariç sadece serum oksidatif stres değerlerinin değerlendirilmesi, oksidatif stres için yeterli olabilir. Bununla birlikte, oksidatif stres değerleri hastalığın şiddetini yansıtmayabilir. Çeşitli çalışmalarda oksidatif stres belirteçlerinin serum düzeyi ölçümlerinde anlamlı değişimlere sebep olduğu gözlenmiştir. Bu çalışmada önemli bir oksidatif stres belirteci olan tiyol/disülfid dengesinin hasta grupta native ve total tiyolde bir azalmaya ve disülfidde bir artışa doğru değiştiğini gözlemledik. $\mathrm{Bu}$ değişiklik hasta ve kontrol grupları arasında native tiyol ve total tiyolde istatistiksel olarak anlamlı iken hasta grubundaki disülfiddeki artış istatiksel olarak anlamlı değildi. Çoklu regresyon analizi, KOM'daki doğal tiyoldeki 
azalmanın yaş, VKI veya cinsiyetten bağımsız olduğunu ortaya koydu. Bu, KOM etiyolojisinde oksidan kapasite tutulumuna katkıda bulunabilir. $\quad \mathrm{Bu}$ homeostazın immünetyopatogenezde çok önemli rolünün bulunduğu ve TDH'ındaki bozulmanın oksidatif stres ve doku inflamasyonu sayesinde hastalığ tetiklediği düşündürtmektedir. $\mathrm{Bu}$ çalışmanın sonuçları; tiyol / disülfid homeostazının, KOM etiyopatogenezinde kullanılabileceğini göstermiştir. TDH parametreleri yeni geliştirilen, otomatik bir yöntem kullanılarak ticari olarak kullanılan kitler ile uygun ve doğru bir şekilde ölçülebilmektedir.

Sonuç olarak, mevcut sonuçlar KOM'lu hastalarda dinamik tiyol değişikliklerinin önemli ölçüde bozulduğunu göstermiștir. KOM tedavisinde, antioksidan tedavisi eklemenin ne kadar etkili olabileceği, tedavi modalitelerinin değiştirip değiștirmeyeceğini cerrahinin mutlak üstünlüğünü kırıp kıramayacağını öğrenmek için daha geniş klinik çalışma ve gözleme ihtiyaç bulunmaktadır.

Etik Komite Onayı: Çalışma öncesinde Sağlık Bilimleri Üniversitesi Eğitim ve Araștırma Hastanesi Klinik Araştırmalar Etik Kurulundan 438 sayılı Etik Kurul onayı alınmıştır.

Çıkar Çatışması Onayı: Yazarlar arasında herhangi bir çıkar çatışması olmadığını bildiriyoruz.

Finansal Destek: Yazarlar bu çalışmanın yürütülmesinde finansal destek almadıklarını beyan eder.

Declaration of Conflicting Interests: The authors declare that they have no conflict of interest.

Financial Disclosure: No financial support was received.

\section{KAYNAKLAR}

1. Paksoy M, Aydın S, Eken M, Hardal Ü, Çelebi Ö. Kronik Otitis Mediada Kemik Zincir, Kulak Zarı Perforasyonları ve İşitme Kayıpları ile İlişkisi. Otoskop Derg. 2005; 6: 517.

2. Dayasena RP, Dayasiri MBKC, Jayasuriya C, Perera DSC. Aetiological agents in chronic suppurative otitis media in Sri Lanka. Australas Med J. 2011; 4: 101-4.

3. Vanneste P, Page C. Otitis media with effusion in children: Pathophysiology, diagnosis, and treatment. A review. J Otol. 2019; 14: 33-9.

4. Baysal E, Aksoy N, Kara F, et al. Oxidative stress in chronic otitis media. Eur Arch Otorhinolaryngol. 2013; 270: 1203-8.

5. Valko M, Leibfritz D, Moncol J, et al. Free radicals and antioxidants in normal physiological functions and human disease. Int J Biochem Cell Biol. 2007; 39: 44-84.

6. Birben E, Şahiner UM, Saçkesen C, Erzurum S, Kalaycı 0. Oxidative stres and antioxidant defense. WAO Journal. 2012; 5: 9-19.

7. Erel 0 , Neșelioğlu S. A novel and automated assay for thiol/disulphide homeostasis. Clin Biochem. 2014; 47: 326-32.

8. Hurd TR, Prime TA, Harbour ME, Lilley KS, Murphy MP. Detection of reactive oxygen speciessensitive thiol proteins by redox difference gel electrophoresis: implications for mitochondrial redox signaling. J Biol Chem. 2007; 282: 22040-51.

9. Sezer U, Erciyas K, Üstün K et al. Effect of chronic periodontitis on oxidative status in patients with rheumatoid arthritis. J Periodontol. 2013; 84:78592.

10. Koç S, Aksoy N, Bilinç $\mathrm{H}$, et al. Paraoxonase and arylesterase activity and total oxidative/antioxidative status in patients with chronic adenotonsillitis. Int J Pediatr Otorhinolaryngol. 2011: 75: 1364-7.

11. Gupta SC, Hevia D, Patchva S, et al. Upsides and downsides of reactive oxygen species for cancer: the roles of reactive oxygen species in tumorigenesis, 
prevention, andtherapy. Antioxi Redox Signal. 2012; 16: 1295-322.

12. Dobashi K, Ghosh B, Orak JK, Singh I, Singh AK. Kidney ischemia-reperfusion: modulation of antioxidant defences. Mol Cell Biochem. 2000; 205: 1-11.

13. Gottlieb RA, Mentzer RM. Autophagy during cardiac stress: joys and frustrations of autophagy. Annu Rev Physiol. 2010; 72: 45-59.

14. Turan M, Ucler R, Aslan $M$, et al. Serum paraoxonase and arylesterase activities in patients with chronic otitis media. Redox Rep. 2015; 20: 2415.

15. Yilmaz T, Kocan EG, Besler HT, Yilmaz G, Gursel B. The role of oxidants and antioxidants in otitis media with effusion in children. Otolaryngol Head Neck Surg. 2004;131: 797-803.

16. Garca MF, Aslan M, Tuna B, Kozan A, Çankaya H. Serum Myeloperoxidase Activity, Total Antioxidant Capacity and Nitric Oxide Levels in Patients with Chronic Otitis Media. J Membr Biol. 2013; 246: 51924.

17. Garca MF, Turan M, Avşar B, et al. The evaluation of oxidative stress in the serum and tissue specimens of patients with chronic otitis media. Clin Exp Otorhinolaryngol. 2015; 8: 97-101.

18. Karlı R, Karlı A, Aksoy A, Açıkgöz S, Ayhan E. Orta kulak efüzyonları. Dicle Med J. 2013; 40: 54-6. 